\title{
Owner-Managers' Demographic Characteristics and the Growth of Tanzanian Small and Medium Enterprises
}

\author{
Nsubili Isaga $^{1}$ \\ ${ }^{1}$ School of business, Mzumbe University, Morogoro, Tanzania \\ Correspondence: Nsubili Isaga, School of business, Mzumbe University, Morogoro, Tanzania. E-mail: \\ nisaga@mzumbe.ac.tz
}

Received: February 11, 2014

Accepted: March 26, 2015

Online Published: April 20, 2015

doi:10.5539/ijbm.v10n5p168

URL: http://dx.doi.org/10.5539/ijbm.v10n5p168

\begin{abstract}
This paper aims to contribute to the understanding of the demographic factors that influence the growth of Small and Medium-sized enterprises (SMEs) in Tanzania. A survey method was used to gather data from 300 small business owners and managers located in selected cities in Tanzania. Multiple regression analysis was conducted to analyse the influence of owner-manager demographic factors on the growth of SMEs. Three indicators for growth namely employment, sales and assets were used to measure growth. The results suggests that workshop, vocational training, industrial and managerial experience and family background do influence the growth of SMEs. Entrepreneurial experience and level education successfully completed by the owner-manager are not important in explaining SMEs growth. The results suggest that policy measures that promote workshops, role models and previous experiences may have the greatest impact in terms of helping to facilitate SMEs growth in Tanzania. However, the results are limited to a single survey and the data was collected from only one sector (furniture sector) in Tanzania. Replication of this study using larger samples to different sectors and a broader geographic base is suggested for cross validation purposes.
\end{abstract}

Keywords: owner-manager, demographic factors, SMEs growth, Tanzania

\section{Introduction}

It has been widely recognized that there is a positive correlation between Small and medium-sized enterprises (SMEs) and economic growth (Urban \& Naidoo, 2012; Batsakis, 2014). Due to this recognition, most countries are focussing on stimulating the economic growth through the development of SMEs (Robson, Haugh, \& Obeng, 2009; Pinho \& De Sa, 2014). Actually, empirical researchers suggest that SMEs bring great economic benefits in terms of employment creation and income generation (Hallberg, 1999; Acs \& Szerb, 2007; Kang \& Heshmati, 2008). For example in Europe $99.8 \%$ of business enterprises are SMEs that employ two thirds of the total workforce (World Bank, 2007).

Like many other countries, Tanzania has recognized the importance of SMEs for economic development and poverty alleviation. Due to this recognition, the Tanzanian government has introduced various policies and programmes intended to support the development of SMEs. Unfortunately, despite the existence of various programmes, only a few SMEs have managed to grow and expand while the majority have declined or remained stagnant. In response to this problem various researches connected to the growth of SMEs have been conducted in Tanzania. These include the role of credit (Kuzilwa, 2005), the macroeconomic environment (Trulsson, 2000), institutional barriers (Nkya, 2003), sources of finance (Bagachwa, Harris, \& Tinios, 1993; Verspreet \& Berlange, 1998; Naliotela \& Elias, 2003), firm characteristics (Satta, 2003), strategy (Mbwambo, 2005), efficiency (Bagachwa \& Mbele, 1995; Wangwe, Semboja, \& Nyanga, 1998), firm size, investment in information technology (Admassie, 2002) and capital (Kimeme, 2005).

Through a review of previous research regarding business growth in Tanzania, the Authors found that most of the studies have focused on external factors and firm characteristics. In line with such findings, several initiatives and programmes in Tanzania are more focused on solving environmental problems such as providing government assistance, the role of banks, and providing infrastructure and competition, while ignoring the individual running the firm. Although some of the issues addressed in these studies have changed, the performance of the SMEs sector in Tanzania has not yet been impressive. This suggests the need to further investigate the factors that influence SMEs growth from different angles. 
Owing to the crucial role played by individuals in these firms, several studies worldwide have acknowledged the importance of entrepreneurs for the growth of SMEs. In fact, most of the SMEs depend on the entrepreneur for their survival and development (Frese, 2000). Usually the entrepreneur is the one who makes important decisions concerning products, markets, motivation of employees, expansion plans and other strategic decisions concerning the firm (Frese, 2000). Thus, this leads to the possibility that a large proportion of the difference in performance among SMEs can be explained by the individual entrepreneurs (Hall, 1995; Shane, 2007; Batsakis, 2014 ). This study used the same approach by following the literature which views entrepreneurs' characteristics as an important determinant of the intention to become an entrepreneur as well as the subsequent performance of the firm (Stanworth \& Curran, 1976; Cromie, 2000; Kuratko \& Hodgetts, 2001; Frese, Van Gelderen, \& Ombach, 2000; Rauch \& Frese, 2007b). By analysing the owner-managers' background (demographic) characteristics as well as the relationship between those characteristics and their firms' growth, this study tests the applicability of the human capital theories to Tanzania's settings. Apart from testing the human capital theories, this study contributes to a better understanding of human capital by providing further evidence about individual factors that influence SMEs growth. Therefore, this study provides answer to the following key research question:

To what extent do demographic factors influence the growth of SMEs?

In this study, the terms entrepreneur and owner-manager are used interchangeably to define a person who both owns the firm and takes overall responsibility for the strategic and operational direction of the business.

\section{Literature Review}

Previous studies have identified demographic factors such as age, education, experience, and family background that contributes to the success of entrepreneurs (Kirby, 2003; Wright, Hmieleski, Schrader, \& Siegel, 2007; Unger, Rauch, Frese, \& Rosenbusch, 2009a; Blackburn, Hart, \& Wainwright, 2013; Batsakis, 2014). In this study, the influence of an entrepreneur's education, experience, age and family background on the growth of SMEs is examined. These factors were chosen because various researchers had found a significant relationship between these factors and the growth of SMEs (Storey, 1994; Wiklund \& Shepherd, 2003b; Barringer, Jones, \& Neubaum, 2005; Littunen \& Virtanen, 2006; Bigsten \& Gebreeyesus, 2007; Goedhuys \& Sleuwaegen, 2010).

\subsection{Education}

Education is one of the key components of human capital (Becker, 1993). This component is the source of knowledge, skills, discipline, motivation and self-confidence (Cooper, Gimenogascon, \& Woo, 1994). Building upon the human capital theory, much research has been done to examine the effect of education on the performance of SMEs (for example see Kirby 2003; Wright et al., 2007; Schrader and Siegel 2007; Unger et al. 2009a). The assumption lies in the notion that individuals with a higher level of education are able to manage their firms more effectively than individuals with a lower level of education (Cooper, Folta, Gimeno-Gaswpscon, \& Woo, 1992; Storey, 1994; Rutashobya, 1995; Trulsson, 2000; Mead \& Liedholm, 1998; Wiklund \& Shepherd, 2003a). Empirically, the effect of education has been widely studied with mixed results. Due to the mixed results, the relationship between education and the growth of SMEs is still an unsettled issue (i.e. positive, neutral or negative). For instance, some studies show a positive relationship between education and the growth of SMEs (Cooper et al., 1992; Yusuf, 1997; Watson, Stewart, \& BarNir, 2003; Barringer et al., 2005; Kim, Aldrich, \& Keister, 2006), while other studies show a negative relationship between the two (Pickles \& O'Farrell, 1987; Stuart \& Abetti, 1990; Johnson, Conway, \& Kattuman, 1999; Bartlett \& Bukvi-ì, 2001). Subsequently, other studies have found that education does not matter in explaining the growth of SMEs (Alvarez \& Crespi, 2003; Silva \& Santos, 2012; Blackburn, Hart, \& Wainwright, 2013). By the look of things, it can be argued that whether or not education is significant depends on the type of education entrepreneurs enjoyed as well as the type of industry the business belongs to (Barringer \& Jones, 2004; Dimov \& Shepherd, 2005). Supported in most of the literature, it can be argued that the entrepreneur's educational background can include several types and means of education. Thus, besides formal education, in this study the educational background of the entrepreneur was also measured in terms of workshops attended and specialised vocational education. Therefore, with regard to the entrepreneur's education this study postulates the following:

H1.1: Formal education of entrepreneurs positively influences the growth of SMEs.

H1.2: Vocational carpentry education is positively influences the growth of SMEs.

H1.3: Workshops attended by entrepreneurs positively influence the growth of SMEs.

\subsection{Experience}

Like education, prior experience is also one of the most frequently examined components of human capital. Through experience people gather information and develop skills that are useful across different occupations 
(Ucbasaran, Westhead, \& Wright, 2008). To date, various dimensions of prior experience have been found in the literature. But the most frequently mentioned types of experience are entrepreneurial experience, management experience and industrial experience (Unger et al., 2009a). These three types of experience are considered to be important in determining the growth of SMEs (Shane \& Khurana, 2003; Unger et al., 2009a). For instance, it is suggested that people who enter an area with which they are well acquainted have a better chance of being successful in their business (Basu \& Goswami, 1999; Dobbs \& Hamilton, 2007). Those people with prior experience in an industry often have a better understanding than others of how to meet demand conditions in that market, develop access to market information and business networks and improve managerial capability (Basu \& Goswami, 1999; Dobbs \& Hamilton, 2007; Shane, 2007). Furthermore, extant research suggests that people with more start-up experience are more likely to have gathered much of the valuable information relating to business creation and growth (Politis, 2005; Unger et al., 2009a). The information obtained can enhance the reputation and broadens the social and business networks which, in turn, lead the business to growth (Littunen \& Virtanen, 2006). Researchers showed that entrepreneurs with more management experience tend to form ventures that have greater employment and sales growth than founders with less management experience (Duchesneau \& Gartner, 1990; Lee \& Tsang, 2001; Bigsten \& Gebreeyesus, 2007; Unger et al., 2009a). These entrepreneurs are able to manage their firms more effectively because previous experience from managing a business provides training in many of the skills needed for recognising and acting on entrepreneurial opportunities, including negotiation, decision making styles, ways to serve markets, and methods for dealing with customers and employees (Shane, 2007). Considering the above discussion, the following research hypotheses are proposed

H2.1: Entrepreneurial experience of entrepreneurs positively influences the growth of SMEs.

H2.2: Management experience of entrepreneurs positively influences the growth of SMEs.

H2.3: Industrial experience of entrepreneurs positively influences the growth of SMEs.

\subsection{Age}

Another important demographic characteristic that influences the growth of SMEs is the age of the entrepreneur. Unlike the entrepreneurs' experience which has a positive effect on the growth of SMEs, the relationship between the age of an entrepreneur and the growth of SMEs has revealed conflicting results. For instance, some findings (e.g., Davidson, 1991; Storey, 1994; Woldie, Leighton, \& Adesua, 2008) have supported the argument that younger managers are more likely to be successful in their firms than older managers because younger managers have more energy, higher aspirations and are more likely to be committed to working long hours, which are generally necessary for a business to be successful. On the other hand, older managers are likely to have reached their final aspirations and thus growth is of little importance. A different set of studies argues that older managers are more likely to be successful in their firms than younger managers (Harada, 2003; Littunen \& Virtanen, 2006). The logic is that older managers are more experienced and have gone through many challenges, which make them strong and confident. Thus, in accordance with the previous findings it can be said that whilst younger managers may have more energy to work, they lack the business experience. On the other hand, older managers may have much experience, but they lack sufficient energy to work (Cortes, Garcia, \& Ramon, 2008). Due to these conflicting messages, one argument, which is a combination of the two, can be put forward (Storey, 1994): middle-aged entrepreneurs are likely to have experience and more energy, and as such they are most likely to establish and manage a business which will grow faster than is the case for younger ones. In this regard, empirical studies have found an inverted U-shaped relationship between the entrepreneurs' age and the growth of SMEs (Reynolds \& White, 1997; Van Praag, 2003). Based on this observation, it was hypothesised that:

$\mathrm{H}$ 3: The age of entrepreneurs has an inverted U-shaped relationship with the growth of SMEs.

\subsection{Family Background}

The knowledge required to run a business can also be learned through observing others. Building upon this proposition, researchers have argued that the children of entrepreneurs should be more likely to be self-employed than other people. Scholars have suggested various reasons as to why the children of entrepreneurs are more likely to be self-employed. These factors are generally drawn from exposure and closure mechanisms (Kim et al., 2006; Sørensen, 2007). Following the review of the literature on family background, it is clear that the children of entrepreneurs should be more likely to form successful businesses than other people (Duchesneau \& Gartner, 1990; Cooper et al., 1992; Mungai \& Velamuri, 2010). It is assumed that having at least one self-employed parent not only helps to develop the human capital of the child but also modifies expectations about what business ownership entails (Niittykangas \& Tervo, 2005). Furthermore, it is suggested that these individuals are more likely to be successful in their businesses for several reasons, such as an ability to seek managerial expertise from their parents in case of business problems, easier access to information on the market as well as 
on other related issues (Duchesneau \& Gartner, 1990; Ardichvili, Cardozo, \& Ray, 1998; Sørensen, 2007; Krauss, Frese, Friedrich, \& Unger, 2005; Mungai \& Velamuri, 2010). Therefore, this study aimed at testing whether coming from an entrepreneurial family has any significant influence on SMEs growth, by hypothesising that:

$\mathrm{H}$ 4: Coming from an entrepreneurial family positively influences the growth of SMEs.

\section{Method}

\subsection{Research Method}

A major difficulty in studying SMEs in most African countries (including Tanzania) is the absence of a proper sampling framework. Due to this, Researchers were forced to use non-probability sampling, namely purposeful sampling. This approach is commonly used in Tanzania due to the lack of an accurate and up-to-date sampling frame (Nchimbi, 2002). With this approach, efforts were therefore made to approach the respondents who fitted our study objectives. Since this study aimed to examine the demographic factors that influence the growth of SMEs, the respondents selected had to be the owner-managers of a firm (or one of them, if a firm had more than one owner-manager. In this study, the term SMEs is used interchangeably with small business to describe small and medium-sized enterprises. In Tanzania, a micro enterprise is defined as a firm with fewer than five employees, whereas a small firm is a firm with 5 to 49 employees and a medium-sized enterprise is a firm with 50 to 99 employees. Any firm with 100 employees or more is regarded as a large enterprise (see Table 1). In the case where an enterprise falls under more than one category, the level of investment would be the deciding factor.

Table 1. SMEs in Tanzania

\begin{tabular}{lll}
\hline Category & Number of employees & $\begin{array}{l}\text { Capital invested in } \\
\text { machinery (Tshs) }\end{array}$ \\
\hline Micro enterprises & $1-4$ & Up to 5 million \\
Small enterprises & $5-49$ & $5-200$ million \\
Medium-sized enterprises & $50-99$ & $200-800$ million \\
\hline
\end{tabular}

In order to reduce bias, regional centres known for their furniture industry were identified with the help of the Small Industry Development Organisation (SIDO). This resulted in the selection of the Dar es Salaam, Arusha, Morogoro and Iringa regions. By choosing these four regions, a spread across the country was ensured. Furthermore, in these regions, all the mentioned centres were visited in which streets of high and low concentration respectively were identified. It was decided that in high-concentration streets the fieldworker should select one in every three enterprises found, while for the low-concentration streets, the fieldworker would select one in every two enterprises she came across.

\subsection{Data Collection and Sample}

The survey data was collected through a structured questionnaire based on the literature study. Before conducting the fieldwork, the questionnaire was translated from English into Kiswahili (the common language spoken in Tanzania). In order to ensure accurate translation, the Kiswahili questionnaire was given to another linguist who translated it back into English. Finally, the fieldworker compared both versions, and a few minor changes were made. Subsequently, a pilot test of the questionnaire was undertaken-as recommended by Baker, (2003) \& Saunders, Phillip, \& Thornhill, (2003) — on a sample of 20 people to determine whether the questions were easy to understand and to answer, and to test the reliability and validity of each question in capturing the information desired. Ultimately, 300 owner-managers participated in the fieldwork study.

\subsection{Operationalization of Study Variables}

\subsubsection{Firm Growth}

The dependent variable in this study is firm growth. This growth can be measured by several attributes such as: sales, employment, assets, profit, market share and productivity. Firm growth, in this study, is defined in terms of change in the level of sales, change in the value of assets and change in the number of employees. Furthermore, it is worth noting that researchers encounter problems in obtaining financial data, especially when dealing with private firms (Dess \& Robinson, 1984). This is because many owner-managers of SMEs often do not keep proper accounting records and when they do, they are often not prepared to disclose them to third parties. Because of this problem, subjective measures were used to obtain information regarding growth in sales and assets. The respondents in this study were asked to rate their firms performance ranging from 1 to 3 in relation to 
whether their firm's sales and assets had decreased, remained the same or increased over the period of study (2003-2007 and 2005-2007 for sales, and 2003-2007 for assets). The researcher coded 1 as decline, 2 remain the same and 3 increase in firms sales and assets. A 3 point scale was adopted because it is an easy approach for the respondents to understand and express their views. In fact, during pilot study, Researcher revealed that respondents were more able to express their performance on the three scales than 5 point scale. To obtain employment growth data, the respondents were asked about the number of employees (including the owner-manager(s) and their relatives) as of January for each year from 2003 to 2007. Accordingly, employment growth was measured over a period of three (2005-2007) and five years (2003-2007). Additionally, a relative growth measure was used to calculate employment growth both for a three year and a five year period.

In this study, growth is measured by using different indicators as well as multiple time intervals. However, our pilot project revealed that the results regarding assets growth as measured over two different time periods showed hardly any significant differences between a three-year period and a five-year period. In fact the participants preferred their assets growth to be assessed over a five-year period rather than a three-year period, as they argued that it is more difficult to discern assets growth over a short period of time. As a consequence it was decided that in this study assets growth is measured over a five-year period only, whereas sales and employment growth is measured over two periods ( 3 and 5 years).

\subsubsection{Demographic Characteristics}

A number of variables were used to explore the entrepreneur's demographic characteristics, such as age, education, experience and family background. Three aspects were used to measure education, namely, the level of formal education, carpentry education and workshops. The structure of formal education in Tanzania consists of three levels namely: primary, secondary and higher education. Basic or first level education constitutes seven years of primary education. Secondary or second level education consists of Ordinary level (which is four years post primary education) and Advance level (which is two years post Ordinary level). Higher education or third level includes programmes and courses offered by higher education institutions such as universities. To measure level of education, the respondents were asked to indicate the level of education they have successful completed. In addition to the question focusing on formal education, there was another question which intended to find out whether or not the respondents had attended any vocational training and particularly carpentry training. The respondents were also asked if they had attended any workshops since starting their business. Three aspects were used to measure the entrepreneurs previous experience. These include entrepreneurial, managerial and industrial experience.

Table 2. Operationalization of the demographic characteristics

\begin{tabular}{|c|c|c|}
\hline Variable & & Measurement \\
\hline Age & & Entrepreneur's age in categories \\
\hline \multirow{3}{*}{ Education } & Level of formal education & Level of formal education the entrepreneur had successfully completed \\
\hline & Vocational training & $\begin{array}{l}\text { Whether or not the entrepreneur had attended one or more courses offered by } \\
\text { vocational training colleges }\end{array}$ \\
\hline & Workshop attended & $\begin{array}{l}\text { Whether or not the entrepreneur had attended one or more workshops since } \\
\text { starting up in business }\end{array}$ \\
\hline \multirow{3}{*}{ Experience } & Entrepreneurial & $\begin{array}{l}\text { Whether or not the entrepreneur had previously been involved in venture } \\
\text { creation }\end{array}$ \\
\hline & Managerial & $\begin{array}{l}\text { Whether or not the entrepreneur had managerial experience prior to starting } \\
\text { the business }\end{array}$ \\
\hline & Industrial & $\begin{array}{l}\text { Whether or not the entrepreneur had experience in the sector the current firm } \\
\text { is in }\end{array}$ \\
\hline Family background & & Whether or not the entrepreneur comes from an entrepreneurial family \\
\hline
\end{tabular}

\section{Empirical Results}

A sample of 300 entrepreneurs was used in this study. Among the 300 respondents, $99.0 \%(n=297)$ were male and $1.0 \%$ were female. The lack of female entrepreneurs may be due to cultural or normative beliefs about a woman's role in society in Tanzania, or it may be due to the fact that the business environment is less accommodating to female-owned businesses. This reflects findings from other studies which show that males participate more in the manufacturing sector than in sectors such as food-vending or garment-making (see, for 
example, Rutashobya, 1995). The findings also showed that most of the entrepreneurs in our study $(86.7 \%)$ were married, $13.0 \%$ were not married, while $0.3 \%$ were divorced. The majority of the respondents $(46.3 \%)$ were aged between 30 and 40 years old at the time of the interview, while 29.7 percent of the respondents were below 30 years of age, and 24.0 percent were above 60 years old. With respect to the formal educational background of the respondents, the majority of them had only completed primary school, with $69.7 \%$ in this category. Very few (3.3\%) had attained an advanced level of secondary school education or a degree. Moreover, the findings indicate that over half of the respondents $(57.0 \%)$ have attended vocational training, offered by various colleges in Tanzania. Interestingly, the majority $(51.7 \%)$ of these respondents attained carpentry education. $56.7 \%$ of the respondents had never attended workshops. Only $43.3 \%$ of the respondents had attended various workshops since they started their current business. Three aspects were used to measure the entrepreneurs' previous experience. The finding indicates that $40.7 \%$ of the respondents had entrepreneurial experience prior to starting their current business. Likewise, $60.0 \%$ of the respondents interviewed had managerial experience prior to starting their current business while $51.0 \%$ of the respondents had experience in the same industry they were currently involved in prior starting their own business.

The majority of the firms (74.3\%) in our sample are small-sized. Additionally, more than half of the firms (53.4\%) were established for less than 10 years ago, while only 3.3 percent of the firms were established for more than 25 years ago. 43.4 percent of the firms were established between 10 and 25 years ago. This relatively young age of the firms may be related to the fact that a capitalist system was only introduced in Tanzania in the 1990s. The findings also indicate that the majority of entrepreneurs in the sample (63.0\%) had close relatives who are/were also doing business.

\subsection{Testing the Hypotheses}

The overall objective of this study is to investigate the influence of the entrepreneurs' demographic factors on the growth of SMEs in Tanzania. Multiple regression analysis was employed to examine the demographic factors which explain the growth of SMEs. Before carrying out the analysis, it was important to examine the strength of the relationship among variables used to measure demographic. The correlation matrix reveals a high correlation between managerial and industrial experience $(\mathrm{r}=.883)$. As a remedy for this, Authors decided to combine these two variables into a new variable called previous experience. Factor Analysis of these two variables shows an emergence of a one factor solution which accounted for $65.7 \%$ of the total variance explained. Before multiple regression analysis was applied, ANOVA was used to assess whether the growth of SMEs is different for different age groups. We first compared the mean of SMEs growth for each age group. The mean of SMEs growth for different group ages ranging from 2.62 (40-50 years in a five year period) to 1.67 (above 60 years in a three year period), see Table 3 and 4.

Table 3. Means for SMEs growth

\begin{tabular}{lcccccc}
\hline & & \multicolumn{5}{c}{ Mean } \\
\cline { 3 - 7 } Age & $\mathbf{N}$ & 3 years & 5 years & 3 years & 5 years & 5 years \\
\hline 30 and below & 89 & 2.3708 & 2.5169 & 2.1685 & 2.2697 & 2.5169 \\
$31-40$ & 139 & 2.3885 & 2.5324 & 2.2590 & 2.3309 & 2.5324 \\
$41-50$ & 51 & 2.1961 & 2.6275 & 2.1569 & 2.1765 & 2.6275 \\
$51-60$ & 15 & 2.0667 & 2.6000 & 2.4000 & 2.2667 & 2.6000 \\
Above 60 & 6 & 1.6667 & 2.1667 & 1.8333 & 1.8333 & 2.1667 \\
Total & 300 & 2.3200 & 2.5400 & 2.2133 & 2.2733 & 2.5400 \\
\hline
\end{tabular}

The findings suggest that the mean scores for different age groups are close to each other. Accordingly, ANOVA was used to test whether differences in mean scores across several groups are statistically significant. The finding shows that the p-values for both approaches are greater than 0.05 , which means that there is no significant difference among the age groups. For this reason, age is not included in the regression analysis and such Hypothesis 3 is fully rejected. 
Table 4. ANOVA test on the entrepreneur's age and SMEs growth in a 3-year period

\begin{tabular}{lrr}
\hline SMEs growth measures 3 years & F-value & Significance \\
\hline Sales & 1.875 & .115 \\
Employment & 1.062 & .376 \\
\hline SMEs growth measures 5 years & F-value & Significance \\
\hline Sales & 1.234 & .296 \\
Assets & 1.234 & .296 \\
Employment & .902 & .463 \\
\hline
\end{tabular}

Multiple regressions were used to analyse the relationship between demographic factors and SMEs growth. The results of the multiple regressions are shown in Table 5 and 6 . The findings from these tables suggests that among all three variables which measures education only workshops has a significant influence on SMEs growth both in terms of sales, asset and employment for both time spans and as such sub hypothesis 1.3 is fully accepted. Vocational carpentry education is significant related to sales and assets growth both for three and five years span. Thus sub hypotheses 1.2 is partially accepted. Again, from these tables it can be seen that previous experience (industrial and managerial) is positively significantly related to SMEs growth both in terms of sales, asset and employment. Thus sub hypotheses 2.2 and 2.3 are fully accepted. Unexpectedly, the relationship between entrepreneurial experience and the growth of SMEs was positive but not significant. Thus, sub hypothesis 2.1 is fully rejected. In this study, it is also stated that coming from an entrepreneurial family would positively influence the growth of SMEs. From the regression analysis it is clear that family background and SME growth are related, thus hypothesis 4 is fully accepted.

Table 5. Multiple regressions on the influence of demographic characteristics on Sales growth (5 year period)

\begin{tabular}{|c|c|c|c|c|c|c|}
\hline & \multirow[t]{2}{*}{ Characteristics } & \multirow[t]{2}{*}{ B } & \multirow[t]{2}{*}{ Sig. } & \multicolumn{2}{|c|}{ Collinearity Statistics } & \multirow[t]{2}{*}{$\mathrm{R}^{2}$} \\
\hline & & & & Tolerance & VIF & \\
\hline \multirow[t]{7}{*}{ Sales } & (Constant) & .412 & .012 & & & .513 \\
\hline & Level of education & .024 & .690 & .900 & 1.112 & \\
\hline & Carpentry education & .187 & .056 & .625 & 1.101 & \\
\hline & Workshops & .618 & .000 & .641 & 1.560 & \\
\hline & Entrepreneurial experience & .025 & .686 & .911 & 1.097 & \\
\hline & Previous experience & .478 & .000 & .641 & 1.559 & \\
\hline & Family background & .051 & .033 & .874 & 1.145 & \\
\hline \multirow[t]{7}{*}{ Assets } & (Constant) & 1.106 & .000 & & & .387 \\
\hline & Level of education & .002 & .973 & .900 & 1.112 & \\
\hline & Carpentry education & .046 & .004 & .874 & 1.145 & \\
\hline & Workshops & .323 & .000 & .641 & 1.560 & \\
\hline & Entrepreneurial experience & .056 & .347 & .911 & 1.097 & \\
\hline & Previous experience & .491 & .000 & .641 & 1.559 & \\
\hline & Family background & .077 & .023 & .835 & 1.197 & \\
\hline \multirow[t]{7}{*}{ Employment } & (Constant) & 1.388 & .000 & & & \\
\hline & Level of education & .126 & .175 & .900 & 1.112 & .066 \\
\hline & Carpentry education & -.055 & .561 & .926 & 1.079 & \\
\hline & Workshops & .336 & .049 & .641 & 1.560 & \\
\hline & Entrepreneurial experience & .033 & .734 & .911 & 1.097 & \\
\hline & Previous experience & .596 & .000 & .641 & 1.679 & \\
\hline & Family background & .199 & .043 & .903 & 1.108 & \\
\hline
\end{tabular}


Table 6. Multiple regressions on the influence of the demographic characteristics on SMEs growth (three years period)

\begin{tabular}{|c|c|c|c|c|c|c|}
\hline & \multirow[t]{2}{*}{ Characteristics } & \multirow[t]{2}{*}{$\mathrm{B}$} & \multirow[t]{2}{*}{ Sig. } & \multicolumn{2}{|c|}{ Collinearity Statistics } & \multirow[t]{2}{*}{$\mathrm{R}^{2}$} \\
\hline & & & & Tolerance & VIF & \\
\hline \multirow[t]{7}{*}{ Sales } & (Constant) & .207 & .288 & & & .492 \\
\hline & Level of education & .092 & .203 & .900 & 1.112 & \\
\hline & Carpentry education & .092 & .022 & .608 & 1.646 & \\
\hline & Workshops & .730 & .000 & .641 & 1.560 & \\
\hline & Entrepreneurial experience & .058 & .435 & .911 & 1.097 & \\
\hline & Previous experience & .548 & .000 & .641 & 1.559 & \\
\hline & Family background & .012 & .050 & .588 & 1.701 & \\
\hline \multirow[t]{7}{*}{ Employment } & (Constant) & 1.474 & .000 & & & \\
\hline & Level of education & .082 & .305 & .900 & 1.112 & .075 \\
\hline & Carpentry education & .002 & .981 & .926 & 1.079 & \\
\hline & Workshops & .236 & .016 & .641 & 1.560 & \\
\hline & Entrepreneurial experience & -.069 & .407 & .911 & 1.097 & \\
\hline & Previous experience & .092 & .022 & .608 & 1.646 & \\
\hline & Family background & .171 & .047 & .903 & 1.108 & \\
\hline
\end{tabular}

\section{Discussion}

This study tested the positive influence of the demographic characteristics of entrepreneurs on the growth of SMEs. From the findings, it becomes clear that the entrepreneurs' education, previous experience and family background all influence the growth of SMEs.

Specifically, among the variables used to measure education it is only 'workshops attended' that was found to have a significant influence on the growth of SMEs. This positive relationship is consistent across all the five approaches used in this study. This result suggests that workshops attended by entrepreneurs equip them with the knowledge and skills which are needed in order to run a firm successfully. In spite of the importance of workshops for SMEs growth, the finding shows that the majority of the entrepreneurs have never attended workshops since starting their business. This is with the contention of Brush, Greene and Hart (2001), Jayawarna, Macpherson, and Wilson (2007) that workshops and training are important sources of skills and technical knowledge for successful entrepreneurship.

It has also been demonstrated that vocational training and level of education of an owner manager influences the formation and growth of SMEs (Pankhurst, 2010). In this study, Authors did find a partial support for this argument. Specifically, the study found that entrepreneurs who have obtained carpentry education offered by various vocational training colleges were more likely to see their businesses growing in terms of sales and assets. This study is also consistent with an African study conducted by McPherson, (1992) in which it was found that entrepreneurs with vocational training had firms that grew faster than firms run by entrepreneurs without such training.

Previous research indicates that the entrepreneurs' level of formal education is a significant determinant of the growth of SMEs (Unger et al., 2009a). In this study, although the level of education of the entrepreneur is positively related to the growth of SMEs, the strength of this relationship is not statistically significant. This suggests that the level of formal education does not matter in explaining the growth of SMEs in Tanzania. Although this result is also found in another African study (McPherson, 1992), Authors do not have a clear explanation for this. In fact, this is surprising and raises an important question regarding the value of the formal education acquired by these entrepreneurs. However, this result should be read with some caution, because the lack of significance could be due to the fact that the majority of the entrepreneurs in this sample have low levels of formal education. Indeed, in our study $71.4 \%$ were found to have either attained only primary school education or never to have attended school. Alternatively, this finding might partially be due to the fact that only the level, and not the type of formal education, is considered in this analysis.

Another interesting finding was the significant influence of previous experience on the growth of SMEs. In particular, this study suggests that entrepreneurs who have previous experience in the industry in which the current business is based as well as managerial experience were more likely to see their business growing in terms of sales, assets, and employment. These results support the findings from previous studies in which work-experience in the same sector seems to create the knowledge and skills which are needed in order to run a 
firm successfully (Stuart \& Abetti, 1990; Jo \& Lee, 1996; Lee \& Tsang, 2001; Shane \& Khurana, 2003; Colombo \& Grilli, 2005; Dobbs \& Hamilton, 2007; Unger et al., 2009a).

Furthermore, there was no evidence to support the significant influence of entrepreneurial experience on the growth of SMEs. This finding may be surprising, considering previous research findings. However, Brush et al. (2001) have pointed out that entrepreneurial experience is often a criterion that influences start-up funding success, rather than something that predicts later firm performance. An alternative explanation for this absence of relationship may be that knowledge of whether or not there has been previous involvement in venture creation does not provide us with accurate information as to whether these start-up experiences have yielded the necessary skills that are supposed to influence the growth of SMEs. This finding may also be due to the fact that over half $(59.3 \%)$ of the entrepreneurs in our sample had no prior entrepreneurial experience, as the current business was their first venture.

The variable family background is one of the great interests in the literature. In this study, over half (63.0\%) of the entrepreneurs in our sample came from an entrepreneurial family. Furthermore, this study found that entrepreneurs who came from entrepreneurial families are more likely to experience growth in their businesses than people without such a background. This is consistent with the contention that children of entrepreneurs are more likely to become successful businesses owners than children of other people (Rose, Kumar, \& Yen, 2006; Sørensen, 2007; Mungai \& Velamuri, 2010).

Contrary to what was expected, the age of the entrepreneur was not significantly related to SMEs growth in this study. This is, however, not surprising, because some of the previous studies have also found the same results. For instance, Stuart and Abetti (1990) have found that the age of the entrepreneur is not related to performance. In this study, the non-significant result may be attributed to the fact that the majority of the entrepreneurs in our sample are in the same age category. Actually, almost half of the respondents were between 30 and 40 years of age at the time of the interview.

The finding that vocational carpentry education is not related to employment growth was unexpected. With respect to vocational carpentry education, it is possible that most of the owner-managers who have received carpentry education feel reluctant to employ an additional worker. Since these entrepreneurs already have carpentry skills, it could well be that they do not need extra carpentry skills through hiring new employees who could contribute their talent. Perhaps it takes times for these entrepreneurs to employ an additional worker. This argument corresponds to Kessy and Temu (2010), who revealed that the majority of the entrepreneurs in Tanzania employ an additional worker only after a long period of accumulating assets and revenue. On the other hand, the possible reason for this result could be largely attributed to the methodological approaches used. This might be an indication that factors affecting sales or assets do not necessary affect employment growth (Delmar, 1997; Jansen, 2009).

\section{Conclusion and Recommendations}

Guided by the research hypotheses presented earlier, this study carried out a cross-sectional design from which the data was collected through the survey method in order to attain this general objective. Ultimately, 300 entrepreneurs (representing SMEs) within the furniture sector in four different regions in Tanzania participated in the fieldwork study. Multiple regression analysis was used to examine the relationship between the hypothesised relationships. In short, the findings suggest that certain demographic characteristics of the entrepreneurs are indeed significant predictors of the growth of SMEs in the furniture sector in Tanzania. As indicated previously, demographic characteristics were represented by four characteristics namely: age, education, previous experience, and family background of the owner-manager. In short, the findings suggest that workshops attended, previous experience, and family background affect the growth of SMEs both in terms of sales, assets, and employment growth. Vocational carpentry education seems to affect the growth of SMEs in sales and assets only. This study, therefore, concludes that certain demographic characteristics of entrepreneurs influence the growth of SMEs in Tanzania.

The study makes a number of contributions with respect to matters of both theoretical and practical concern. First, our study contributes to existing knowledge by showing that different types of education, previous experience and family background significantly explain the variance in the growth of SMEs. Specifically, with regards to education, the findings show that not all types of education play an equal role in explaining the growth of SMEs. In fact, education received in the form of workshops showed a stronger relationship with SMEs growth than other types of education. Therefore, future research should include more types of education and experience in order to have a clearer understanding of the influence of these factors on SMEs growth. With regard to the growth measures, the findings contribute to the existing knowledge by showing that sales, assets and 
employment are not interchangeable criteria for measuring the growth of SMEs.

\section{Acknowledgements}

The financial support of the Netherlands Organisation for International Cooperation in Higher Education (Nuffic), through MUMBA project (Strengthening the Capacity of Mzumbe University to Address National Needs in Enhancing the Business Environment in Tanzania).

\section{References}

Acs, Z. J., Desai, S., \& Hessels, J. (2008). Entrepreneurship, economic development and institutions. Small Business Economics, 31(3), 219-34. http://dx.doi.org/10.1007/s11187-008-9135-9

Admassie, A. (2002). Explaining the high incidence of child labour in sub-Saharan Africa. African Development Review-Revue Africaine de Developpement, 14(2), 251-75.

Alvarez, R., \& Crespi, G. (2003). Determinants of technical efficiency in small firms. Small Business Economics, 20, 233-244. http://dx.doi.org/10.1023/A:1022804419183

Ardichvili, A., Cardozo, R., \& Ray, S. (2003). A theory of entrepreneurial opportunity identification and $\begin{array}{lllll}\text { development. Journal of Business } & \text { Venturing, }\end{array}$ http://dx.doi.org/10.1016/S0883-9026(01)00068-4

Bagachwa, M. S. D., Harris, A. H., \& Tinios, P. (1993). Small Scale urban enterprises in Tanzania: Results from a 1991 survey. Working paper No.44, Cornell food and Nutrition Policy program.

Baker, M. (2003). Business and Management Research, How to Complete your Research Project Successfully. Scotland: Westburn.

Barringer, B. R., Jones, F. F., \& Neubaum, D. O. (2005). A quantitative content analysis of the characteristics of rapid-growth firms and their founders. Journal of Business Venturing, 20(5), 663-687. http://dx.doi.org/10.1016/j.jbusvent.2004.03.004

Barringer, B. R., \& Jones, F. F. (2004). Achieving rapid growth-revisiting the managerial capacity problem. Journal of Business Venturing, 20(5), 663-74. http://dx.doi.org/10.1016/j.jbusvent.2004.03.004

Bartlett, W., \& Bukvi-ì, V. (2001). Barriers to SMEs Growth in Slovenia. MOCT-MOST: Economic Policy in Transitional Economies, 11(2), 177-195.

Basu, A., \& Goswami, A. (1999). South Asian entrepreneurship in Great Britain: Factors influencing growth. International Journal of Entrepreneurial Behaviour and Research, 5(5), 251-275. http://dx.doi.org/10.1108/13552559910300381

Batsakis, K. G. (2014). Impediments on the way to entrepreneurship. Some new evidence from the EU's post-socialist world. Journal of Small Business and Enterprise Development, $21(3)$ 385-402. http://dx.doi.org/10.1108/JSBED-04-2014-0062

Becker, G. S. (1993). Human capital: A theoretical and empirical analysis with specific reference to education. Chicago: University of Chicago Press.

Bigsten, A., \& Gebreeyesus, M. (2007). The small, the young and the productive: Determinants of manufacturing firm growth in Ethiopia. Economic Development and Cultural Change, 55, 813-840. http://dx.doi.org/10.1086/516767

Blackburn, R. A., Hart, M., \& Wainwright, T. (2013). Small business performance: Business, strategy and owner manager characteristics. Journal of Small Business and Enterprise Development, 20(1), 8-27. http://dx.doi.org/10.1108/14626001311298394

Brush, C. G., Greene, P. G., \& Hart, M. M. (2001). From initial idea to unique advantage: The entrepreneurial challenge of constructing a resource base. Academy of Management Executive, 15(1), 64-80. http://dx.doi.org/10.5465/AME.2001.4251394

Colombo, M. G., \& Grilli, L. (2005). Founders' human capital and the growth of new technology-based firms: A competence-based view. Research Policy, 34(6), 795-816. http://dx.doi.org/10.1016/j.respol.2005.03.010

Cooper, A. C., Folta, F., Gimeno-Gascon, F. J., \& Woo, C. Y. (1992). Entrepreneurs, process of founding, and new firm performance. In Sexton, D., \& Kassandra, J. (Eds.), The State of the Art in Entrepreneurship. Boston, MA: PWS Kent Publishing Co.

Cooper, A. C., Gimeno-Gascon, F. J., \& Woo, C. Y. (1994). Initial Human and Financial Capital As Predictors of 
New Venture Performance. Journal of Business Venturing, 9(5), 371-395. http://dx.doi.org/10.1016/0883-9026(94)90013-2

Cortes, E. C., Garcia, L. R., \& Ramon, D. Q. (2008). Family factors and international compromise: Empirical evidence in Spanish businesses. Cuadernos de Economia y Direccion de la Empresa, 35, 7-27.

Cromie, S. (2000). Assessing entrepreneurial inclinations: Some approaches and empirical evidence. European Journal of Work and Organizational Psychology, 9(1), 7-30. http://dx.doi.org/10.1080/135943200398030

Davidsson, P. (1991). Continued Entrepreneurship-Ability, Need, and Opportunity As Determinants of Small Firm Growth. Journal of Business Venturing, 6(6), http://dx.doi.org/10.1016/0883-9026(91)90028-C

Delmar, F. (1997). Measuring growth: Methodological considerations and empirical results. In R Donckels \& A Miettinen (Eds.), Entrepreneurship and SMEs Research: On its Way to the Next Millennium (pp. 199-216).

Dess, G. G., \& Robinson, R. B. (1984). Measuring organizational performance in the absence of objective measures: The case of the privately-held firm and conglomerate business unit. Strategic Management Journal, 5, 265-273. http://dx.doi.org/10.1002/smj.4250050306

Dimov, D. P., \& Shepherd, D. A. (2005). Human capital theory and venture capital firms: Exploring "home runs" and "strike outs". Journal of Business Venturing, 20(1), 1-21. http://dx.doi.org/10.1016/j.jbusvent.2003.12.007

Dobbs, M., \& Hamilton, R. T. (2007). Small business growth: Recent evidence and new directions. International Journal of Entrepreneurial Behaviour and Research, 13(5), $296-322$. http://dx.doi.org/10.1108/13552550710780885

Duchesneau, D. A., \& Gartner, W. B. (1990). A Profile of New Venture Success and Failure in An Emerging Industry. Journal of Business Venturing, 5(5), 297-312. http://dx.doi.org/10.1016/0883-9026(90)90007-G

Frese, M. (2000). Success and failure of micro business owners in Africa: A Psychological Approach. Westport: Quorum Books.

Frese, M., Van Gelderen, M., \& Ombach, M. (2000). How to plan as a small scale business owner: Psychological process characteristics of action strategies and success. Journal of Small Business Management, 38(2), 1-18.

Goedhuys, M., \& Sleuwaegen, L. (2010). High growth entrepreneurial firms in Africa: A quantile regression approach. Small Business Economics, 34, 31-51. http://dx.doi.org/10.1007/s11187-009-9193-7

Hall, G. (1995). Surviving and Prospering in the small firm sector. London: Routledge.

Hallberg, K. (1999). Small and Medium Scale Enterprises: A Framework for Intervention, Small Enterprise Unit (pp. 1-35). Private Sector Development Department, the World Bank.

Harada, N. (2003). Who succeeds as an entrepreneur? An analysis of the post-entry performance of new firms in Japan. Japan and the World Economy, 15(2), 211-22. http://dx.doi.org/10.1016/S0922-1425(02)00002-6

Jayawarna, D., Macpherson, A., \& Wilson, A. (2007). Training commitment and performance in manufacturing SMEs: Incidence, intensity and approaches. Journal of Small Business and Enterprise Development, 14(2), 321-38. http://dx.doi.org/10.1108/14626000710746736

Jo, H., \& Lee, J. (1996). The relationship between an entrepreneur's background and performance in a new venture. Technovation, 16(4), 161-171. http://dx.doi.org/10.1016/0166-4972(96)89124-3

Johnson, P., Conway, C., \& Kattuman, P. (1999). Small business growth in the short run. Small Business Economics, 12(2), 103-112. http://dx.doi.org/10.1023/A:1008006516084

Kang, J. H., \& Jin, B. (2007). Determinants of born global firm growth in the apparel industry: A Korean case. Journal of the Textile Institute, 98(2), 137-45. http://dx.doi.org/10.1533/joti.2005.0283

Kang, J. W., \& Heshmati, A. (2008). Effect of credit guarantee policy on survival and performance of SMEs in Republic of Korea. Small Business Economics, 31(4), 445-62. http://dx.doi.org/10.1007/s11187-008-9144-8

Kessy, S., \& Temu, S. S. (2010). The impact of training on performance of micro and small enterprises served by microfinance institutions in Tanzania. Research Journal of Business Management, 4(20), 103-11. http://dx.doi.org/10.3923/rjbm.2010.103.111

Kim, P., Aldrich, H., \& Keister, L. (2006). Access (Not) Denied: The Impact of Financial, Human, and Cultural Capital on Entrepreneurial Entryin the United States. Small Business Economics, 27(1), 5-22. 
http://dx.doi.org/10.1007/s11187-006-0007-x

Kimeme, J. A. (2005). Factors for entrepreneurial success in Tanzania, The case of fish traders. A Dissertation for Award of PHD Degree Sokoine University of Agriculture, Morogoro, Tanzania.

Kirby, A. D. (2003). Entrepreneurship. Maidenhead: MCGraw-Hill Education.

Krauss, S. I., Frese, M., Friedrich, C., \& Unger, J. M. (2005). Entrepreneurial orientation: A psychological model of success among southern African small business owners. European Journal of Work and Organizational Psychology, 14(3), 315-344. http://dx.doi.org/10.1080/13594320500170227

Kuratko, D. F., \& Hodgetts, R. M. (2001). Entrepreneurship: A contemporary Approach. Orlando FL: The Dryden Press: Harcourt Brace College Publishers.

Kuzilwa, J. (2005). The Role of Credit for Small Business Success. Journal of Entrepreneurship, 14(2), 131-61. http://dx.doi.org/10.1177/097135570501400204

Lee, D. Y., \& Tsang, E. W. K. (2001). The effects of entrepreneurial personality, background and network activities on venture growth. Journal of Management Studies, 38(4), 583-602. http://dx.doi.org/10.1111/1467-6486.00250

Littunen, H., \& Virtanen, M. (2006). Differentiating growing ventures from non-growth. The International Entrepreneurship and Management Journal, 2(1), 93-109. http://dx.doi.org/10.1007/s11365-006-7091-x

McPherson, M. A. (1992). Growth and survival of small Southern African Firms. In PhD Dissertation, Michigan State University, East Lansing, Michigan.

Mead, D. C., \& Liedholm, C. (1998). The dynamics of micro and small enterprises in developing countries. World Development, 26(1), 61-74. http://dx.doi.org/10.1016/S0305-750X(97)10010-9

Mungai, E., \& Velamuri, S. R. (2010). Parental Entrepreneurial Role Model Influence on Male Offspring: Is It Always Positive and When Does It Occur? Entrepreneurship Theory and Practice, 35(20), 337-357. http://dx.doi.org/10.1111/j.1540-6520.2009.00363.x

Naliotela, N., \& Elias, E. (2003). Introduction of industrial design engineering concepts to SMEs in Tanzania: Difficulties and possible approaches. Paper presented at the International Conference on Industrial design engineering, 11-13 May University of Dar es Salaam, Tanzania.

Nchimbi, M. I. (2002). Gender and Entrepreneurship in Tanzania, A comparative analysis of Male-Female's start-up motivation, individual characteristics and perceptions of business success. A Dissertation for Award of PHD Degree at the University of Dar es Salaam, Dar es Salaam, Tanzania.

Niittykangas, H., \& Tervo, H. (2005). Spatial variations in intergenerational transmission of self-employment. Regional Studies, 39(3), 319-32. http://dx.doi.org/10.1080/00343400500087166

Nkya, E. (2003). Institutional Barriers to Small-Scale Business Development: A need for flexibility in Tanzanian Tax and Regulatory Systems. Journal of Entrepreneurship, 12(1), 43-73. http://dx.doi.org/10.1177/097135570301200103

Pankhurst, K. V. (2010). Learning by experience, work and productivity: Theory and empirical evidence. Journal of Vocational Education \& Training, 62(2), 103-22. http://dx.doi.org/10.1080/13636821003690504

Pickles, A. R., \& O'Farrell, P. N. (1987). An analysis of entrepreneurial behaviour from male work histories. Regional Studies, 21(5), 425-444. http://dx.doi.org/10.1080/00343408712331344588

Pinho, J. C., \& De Sá, E. S. (2014). Personal characteristics, business relationships and entrepreneurial performance: some empirical evidence. Journal of Small Business and Enterprise Development, 21(2), $7-17$.

Politis, D. (2005). The process of entrepreneurial learning: A conceptual framework. Entrepreneurship Theory and Practice, 29(4), 399-424. http://dx.doi.org/10.1111/j.1540-6520.2005.00091.x

Rauch, A., \& Frese, M. (2007a). Born to be an entrepreneur? Revisiting the personality approach to entrepreneurship. In Baum, J. R., Frese, M., \& Baron, R. A. (Eds.), The psychology of entrepreneurship (pp. 41-65). Mahwah, NJ: Erlbaum.

Rauch, A., \& Frese, M. (2007b). Let's put the person back into entrepreneurship research: A meta-analysis on the relationship between business owners' personality traits, business creation, and success. European Journal of Work and Organizational Psychology, 16(4), 353-385. http://dx.doi.org/10.1080/13594320701595438 
Reynolds, P. D., \& White, S. (1997). The Entrepreneurial Process: Economic Growth, Men, Women and Minorities. Westport, CT, US: Quorum Books.

Robson, P. J. A., Haugh, H. M., \& Obeng, B. A. (2009). Entrepreneurship and innovation in Ghana: Enterprising Africa. Small Business Economics, 32(3), 331-350. http://dx.doi.org/10.1007/s11187-008-9121-2

Rose, R. C., Kumar, N., \& Yen, L. L. (2006). Entrepreneurs Success Factors and Escalation of Small and Medium-sized Enterprises in Malaysia. Journal of Social Sciences, 2(3), 74-80. http://dx.doi.org/10.3844/jssp.2006.74.80

Rutashobya, L. K. (1995). Women entrepreneurship in Tanzania: Entry and performance barriers. Research report submitted to OSSREA, Addis Ababa.

Satta, T. A. (2003). Enterprise Characteristics and Constraints in Developing Countries: Evidence from A Sample of Tanzanian Micro and Small-Scale Enterprises. International Journal of Entrepreneurship and Innovation, 4(3), 175-84. http://dx.doi.org/10.5367/000000003101299546

Saunders, M., Phillip, L., \& Thornhill, A. (2003). Research Methods for Business Students (3rd ed.). Harlow: Prentice Hall.

Schrader, R., \& Siegel, D. S. (2007). Assessing the Relationship between Human Capital and Firm performance: Evidence from Technology Based New Ventures. Entrepreneurship, Theory and Practice, 31(6), 893-908. http://dx.doi.org/10.1111/j.1540-6520.2007.00206.x

Shane, S. (2007). A general theory of entrepreneurship: The individual-Opportunity Nexus. Aldershot: Edward Elgar.

Shane, S., \& Khurana, R. (2003). Bringing individuals back in the effects of career experience on new firm founding. Industrial and Corporate Change, 12(3), 519-543. http://dx.doi.org/10.1093/icc/12.3.519

Silva, A. P., \& Santos, C. M. (2012). Financial and Strategic Factors Associated with the Profitability and Growth of SME in Portugal. International Journal of Economics and Finance, 4(3), 46-60. http://dx.doi.org/10.5539/ijef.v4n3p46

Sørensen, J. B. (2007). Closure and Exposure: Mechanisms in the Intergenerational Transmission of Self-employment. In Lounsbury, M. (Ed.), The Sociology of Entrepreneurship (Research in the Sociology of Organizations, Vol. 2, pp. 83-124). Emerald Group Publishing Limited.

Stanworth, M. J. K., \& Curran, J. (1976). Growth and Small Firm-Alternative View. Journal of Management Studies, 13(2), 95-110. http://dx.doi.org/10.1111/j.1467-6486.1976.tb00527.x

Storey, D. J. (1994). Understanding the Small Business Sector. London: Routledge.

Stuart, R. W., \& Abetti, P. A. (1990). Impact of Entrepreneurial and Management Experience on Early $\begin{array}{llll}\text { Performance. Journal of Business } & \text { Venturing, }\end{array}$ http://dx.doi.org/10.1016/0883-9026(90)90029-S

Trulsson, P. (2000). Managing Growth-Perspectives on Achieving Small Enterprise Growth in Tanzania, Uganda and Zimbabwe: Action Programme on Productivity Improvement, Competitiveness and Quality Jobs in Developing Countries. Working Paper.

Ucbasaran, D., Westhead, P., \& Wright, M. (2008). Opportunity Identification and Pursuit: Does an Entrepreneur's Human Capital Matter? Small Business Economics, 30, 153-173. http://dx.doi.org/10.1007/s11187-006-9020-3

Unger, J. M., Rauch, A., Frese, M., \& Rosenbusch, N. (2009a). Human capital and entrepreneurial success: A

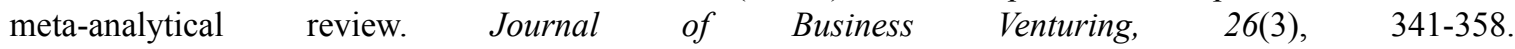
http://dx.doi.org/10.1016/j.jbusvent.2009.09.004

Unger, J. M., Keith, N., Hilling, C., Gielnik, M. M., \& Frese, M. (2009b). Deliberate practice among South African small business owners: Relationships with education, cognitive ability, knowledge, and success. Journal of Occupational and Organizational Psychology, 82(1), 21-44. http://dx.doi.org/10.1348/096317908X304361

Urban, B., \& Naidoo, R. (2012). Business sustainability: empirical evidence on operational skills in SMEs in South Africa. Journal of Small Business and Enterprise Development, 19(1), 146-163. http://dx.doi.org/10.1108/14626001211196451

Van Praag, C. M. (2003). Business Survival and Success of Young Small Business Owners. Small Business 
Economics, 21, 1-17. http://dx.doi.org/10.1023/A:1024453200297

Verspreet, D., \& Berlange, L. (1998). Small Scale enterprise development in Tanzania: Driving forces. Unpublished report, Dar es Salaam, Centre for Economic Studies, Faculty of Economic and Applied Economic Science.

Wangwe, M., Semboja, H., \& Nyanga, A. (1998). Study on Business Contracting Practices in Tanzania. ESRF Economic and Social Research Fund, Dare s Salaam.

Watson, W., Stewart, W. H., \& BarNir, A. (2003). The effects of human capital, organizational demography, and interpersonal processes on venture partner perceptions of firm profit and growth. Journal of Business Venturing, 18, 145-164. http://dx.doi.org/10.1016/S0883-9026(01)00082-9

Wiklund J., \& Shepherd, D. (2003b). Knowledge-based resources, entrepreneurial orientation, and the performance of small and medium-sized businesses. Strategic Management Journal, 24(13), 1307-1314. http://dx.doi.org/10.1002/smj.360

Wiklund, J., Davidsson, P., \& Delmar, F. (2003a). What Do They Think and Feel about Growth? An Expectancy-Value Approach to Small Business Managers' Attitudes Toward Growth. Entrepreneurship Theory and Practice, 27(3), 247-270. http://dx.doi.org/10.1111/1540-8520.t01-1-00003

Woldie, A., Leighton, P., \& Adesua, A. (2008). Factors influencing Small and Medium Enterprises (SMEs): An exploratory study of owner-manager and firm characteristics. Banks and Bank Systems, 3(3), 5-13.

World Bank. (2007). Investment Climate Assessment: Improving Enterprise Performance and Growth in Tanzania. Washington DC: World Bank.

Wright, M., Hmieleski, K. M., Siegel, D. S., \& Ensley, M. D. (2007). The role of human capital in technological entrepreneurship. Entrepreneurship Theory and Practice, 31(6), 791-806. http://dx.doi.org/10.1111/j.1540-6520.2007.00202.x

Yusuf, A. (1997). An Empirical Investigation of the Organisation Life Cycle Model for Small Business Development and Survival in the South Pacific. Journal of Enterprising Culture, 5(4), 423-445. http://dx.doi.org/10.1142/S0218495897000247

\section{Copyrights}

Copyright for this article is retained by the author(s), with first publication rights granted to the journal.

This is an open-access article distributed under the terms and conditions of the Creative Commons Attribution license (http://creativecommons.org/licenses/by/3.0/). 